\title{
E-PANOPTICON OF FACE-TO-DISPLAY WORKERS: FROM THE OFFICE TO THE HOME
}

\author{
${ }^{\mathrm{a}}$ MICHAL BEŇO, ${ }^{\mathrm{b}} \mathrm{JOZEF}$ HVORECKÝ, ${ }^{\mathrm{c} J O Z E F ~ S ̌ I M U ́ T H ~}$ \\ Institute of Technology and Business in České Budějovice, 370 \\ 01 České Budějovice, Czech Republic \\ Vysoká škola manažmentu, 85104 Bratislava, Slovakia \\ email: ${ }^{a}$ beno@mail.vstecb.cz, ${ }^{b}$ hvorecky@mail.vstecb.cz, \\ cjsimuth@vsm.sk
}

\begin{abstract}
Electronic Monitoring (EM) is becoming prevalent, enabling varied and pervasive monitoring of workplaces. The research design was a set of e-mail surveys. Quantitative data were analyzed using cross-tabulation of data, descriptive and chisquare tests statistics. The study provides an overview of e-worker monitoring in five countries. Twenty percent of respondents believe that their organization uses employee monitoring software to track their activities. Almost half of the e-workers believe that their activities are not being tracked by software. Nearby $1 / 10$ of the faceto-display workers surveyed would trust their employer more using EM. Four-fifths of o-display workers surveyed would trust their employer more using EM. Four-fifths of e-workers state that EM affects their productivity. Presented data emphasizes that companies using face-to-display workers monitoring software can negatively affect corre

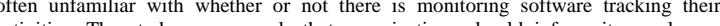
activities before implementation of EM system to facilitate their positive attitudes

Keywords: e-working, e-panopticon of face-to-display workers, software, productivity, V4 and Austria.
\end{abstract}

\section{Introduction}

With the current global Covid-19 pandemic, organizations (big, small, global or local) found themselves in the same work conditions. They have been forced into face-to-display work (eworking) situations. Eurofound (2020) indicated that up to $40 \%$ of working employees in the EU began to e-work full-time as a result of the pandemic. A simple definition of e-working is working at a distance; however, in fact, e-working is far more complex. It is called different names, including teleworking, telecommuting, mobile working, nomadic working and others. It refers to the replacement of telecommunications for any form of work-related travel, thereby removing distance limitations and problems associated with classical commuting. (Nilles, 1998; Hunton and Norman, 2010). Information and communication technologies (ICTs) have released workforces from the constraints of a fixed work place, enabling mundane tasks to be distributed across remote locations (Harrison et al., 2000). Societal changes (the constantly evolving demography, environmental issues and ICT) have an impact on the way we work, and when, how and where we work (Beno, 2019).

Knowledge is seen as central to the success of individuals and organizations and an asset that needs to be managed. The implementation of e-working arrangements during the pandemic has had an enormous impact on the whole organization and employees. This remote-work experiment is an alert to organizations being prepared in the future, when employees will expect to be fully supported in e-working environments as they are in the office. Our ability to cooperate in this type of work habitat makes knowledge management (KM) a necessity. The linkage to how KM powers e-working is visible: it enables findability, connectivity, collaboration and corporate culture. Generally, technology leaders are dependent on KM, but most organizations are behind where they need to be support remote work environments.

Employee monitoring is becoming more common in the workplace (Kirsten and Freeman, 2003; Pitesa, 2012; Kiziloglu, 2018). E-monitoring tools offer managers the ability to continuously evaluate and measure their employee's appraisal (Al-Rjoub et al. 2008). As (Moussa, 2015) underlines, there is no need to police a workforce because no one can work 8 hours without breaks, and a culture of disloyalty and distrust within the organization may emerge.

The growing demand for e-working, the widespread policy drivers and the increase of their usage during Covid-19 have emphasized the need for real-life evidence. Our research was conducted by an online email survey. It addressed the following research questions:

RQ1: Is better to leave room to e-employees instead of spying them?

RQ2: Can e-employee monitoring software (EMS) affect productivity?

RQ3: Is e-employee monitoring software reliable?

The next section provides an account of the concept of eworking and e-monitoring in the workplace. The next part briefly outlines the methodology used in this research. Following paragraph gives an overview of our results. Then the sections presenting our discussion and research limitations follow. The last section comprises our conclusions.

\section{Literature review}

\subsection{E-working}

Telecommuting was first introduced by Jack M. Nilles in 1970s (Nilles et al. 1974). The early main driver was to let employees save costs of commuting to work (Nilles et al., 1974; Nilles, 1997), and later, working at home was linked with gasoline savings (Schiff, 1979).

There is still no uniform definition of teleworking/ telecommuting but several definitions of this phenomenon (Beňo, 2021). The classic definition of teleworking is outdated (Beno, 2018). There are broader approaches to this kind of work (Allen et al. 2015; Nicklin et al. 2016). Some do not require certain regularity and location, while others are fairly traditional about them. The concept of ICT (information and communications technology) enabled work from afar i.e. telework, also known as remote work, virtual work or telecommuting (Gajendran and Harrison, 2007). "Since the idea of telecommuting has been around for decades now, it makes sense that new words and phrases would come to replace what is, in theory, a not-so-new workplace concept” (WorkFlexibility, 2018).

We define e-working as performing job-related work outside the office premises electronically and transferring data to the office/customers/partners or to other locations. Telework covers more than just working at home and communicating with the office via telecommunication tools (Nilles, 1994). In this sense, it includes home-based work, work centres, neighborhood or satellite offices (Nilles, 1994), mobile and virtual work. Kurland and Bailey (1999) defined these four different teleworking types as follows: (1) The Home Office, (2) The Satellite Office, (3) The Neighborhood Work Center and (4) Mobile Working. Thus, face-to-display work can be located at any distance from headquarters, a work center, on the way or in the virtual world. These factors (individual, job, organizational and family/home) impact telework (Baruch and Nicholson, 1997).

\subsection{E-panopticon (e-monitoring) of Face-to-Display workers}

Every manager is concerned about efficient and effective exploitation of working hours and their results. Tracking, control and surveillance of workers at the workplace is therefore not a new concept (Burawoy, 1982; Foucault, 1979). Ajunwa et al. (2017) highlight that there is a rich and varied history of bosses watching over and monitoring their workers, passing through key events and periods of time including warfare, slavery, colonialism and globalization, as well as many other more recent methods used to control and exploit workers.

Many companies spy on their workforce through the e-mail and Internet, sometimes without their awareness and approval. Instant messaging, text messaging, and social media monitoring are also increasing (Laudon and Laudon, 2018). Many have compared workplaces under monitoring to the Panopticon (Liu, 
2017). Ball (2010) identifies three common reasons of emonitoring (EM): (a) to maintain productivity and monitor resources used by employees, (b) to protect trade secrets, and (c) to provide evidence in case of a legal dispute. Ajunwa et al. (2017) add the implementation of these types of EM systems for improving efficiency and innovation as the fourth factor. AlRjoub et al. (2008) add that EM tools provide managers with the ability to continuously evaluate and measure their employee's performance. It implies that employers are capable of micromanaging employees by tracking almost everything. For this reason, we interpret electronic monitoring as any system allowing to track and to supervise every move of e-workers at anytime and anywhere.

The work environment is an elemental site for the development of generic skills such as communication, problem-solving, teamwork, information technology and customer service skills. These skills are crucial in today's workplace because they relate to employability. Beyond, the culture of the workplace needs to support individuals to effectively establish or utilize these skills (Virgona et al., 2003). In the authors' opinion, the ability to develop innovative capacity depends not only on the hard and soft skills, but on the trust, the internal environment of the enterprise and, hence, the up-to-date culture of the workplace. Intrinsic motivation is a triggering element for employees' creativity. During their research, Bernstrøm et al. (2017) concluded that if they are monitored, they are less intrinsically motivated because they feel less trusted. The componential theory of creativity, for example, suggests that an interesting or attractive task or problem increases the employee's tendency to use a creative approach. In other words, the employee tends to search for non-traditional and/or alternative ways of solving work related problems (Amabile et al., 1996, Shin and Zhou, 2017).

In the past, e-workers were selected from among a group of responsible individuals with good behavior. By this act, they were given more freedom from micromanagement. It turns out that e-workers are less prone to misconduct than cubicle workers. Porterfield (2003) recognizes some cases when micromanaging works e.g. line manufacturing occupations where body shapes essentially function as mindless machines. In other words, micromanaging is a great way to reduce job satisfaction, limit creativity, stifle communication, and reduce productivity (Fracaro, 2007).

Workplace surveillance technology is infiltrating the employee's daily environment to monitor their web-browsing patterns, keystrokes, social media posts and even private messaging apps (Solon, 2017). Gartner survey's results found that more than $50 \%$ of corporations are using some type of non-traditional monitoring techniques. Further, $30 \%$ of employees were agreeable with tracking their mail by employer (Kropp, 2019)

Covid-19 has accelerated workplace change. They moved from clearly-defined physical locations to virtual ones. Modern technology enables managers to manage and to track employees from distant locations. Such daily reliance and dependency on technology has created new issues concerning employee' privacy and has added new stress to the employer-employee relationship (Nord et al., 2006). To evoke positive reactions from employees, Kehinde and Okafor (2019) recommend the organization to inform its employees before the EM implementation. To improve employee performance, many organizations are more and more employing electronic performance monitoring (EPM), the so-called an invisible eye (Bhave, 2014). EPM can be utilized to micromanage workforce and to attack privacy, to reduce their job satisfaction, to boost stress and lead into lowtrust and negative work relationships (Schumacher, 2011).

One of the advantages of EM is that it is a useful tool for performance and productivity appraisal and evaluation (AlRjoub et al., 2008; Ciocchetti, 2011; TechRepublic, 2005). On the contrary, numerous studies have documented the negative effects of EM on employee morale and productivity. The monitored employees complain that their surveillance results in paced work, a lack of involvement, a reduced social support from peers and supervisors, and a fear of job loss (Ariss, 2002). Sarpong and Rees (2014) also record that monitoring can be unproductive.

Martin and Freeman (2003) argued that EM creates a "paternalistic" relationship among employers and employees. Lim (2002) adds that employees might feel they are treated like children. But Princi and Krämer (2019) stress that employees who have a trusting relationship with their organization will more likely accept the deployment of an IoT system (Internet of Things implemented as Smart Electronic Monitoring), even if the system is capable of collecting their personal data.

\section{Methods}

Our research was conducted in two phases. First, a literature review was undertaken that examined scholarly findings on eworking and e-monitoring in the workplace. Second, an e-mail survey was undertaken. The structured questionnaire was based on similar published surveys, in particular, on the Clutch 2020 Employee Productivity Survey (Roddy, 2020) focused on pros and cons of employee monitoring. Our insights were drawn from respondents across the Central European Countries: Austria, the Czech Republic, Hungary, Poland and Slovakia. Our main interest addressed their position towards e-monitoring, inter alia the potential changes in their attitude regarding their electronic monitoring after their move to home offices. As a result, their factual geographical locations were not part of our research interest.

All participants engaged in the e-mail survey were fully informed regarding confidentiality, privacy, sensitivity and data protection. Their participation was voluntary, they confirmed it using a consent form.

\subsection{Sample and Sampling procedure}

Before the fieldwork was conducted, the survey instrument was pilot-tested between 9 and 30 November 2020. 1000 questionnaires were sent out, with a response rate of $58.5 \%$. Among them, $45.3 \%$ of the respondents were male, and the median age was 20-39 years. Out of the respondents, $51.5 \%$ were single. The key role of this introductory stage was to form a sample which would only include the employees having jobs requiring an extensive use of computers to accomplish their tasks. Part-time employees and cubicle-only employees were eliminated. Moreover, respondents younger than 20 were omitted. In total, the sample consisted of 585 full time e-workers aged 20 years and above. Consequently, the sample contained a heterogeneous group of professionals working in several areas, including service industry. They all agreed to participate in the next survey under a warranty that their responses to the questionnaire remain anonymous.

\subsection{Measures}

\subsubsection{Monitoring Software}

To map the overall situation, the questionnaire started with the following question: "Does your firm utilize Employee Monitoring Software?” The three-point scale was used: yes - no - unsure.

\subsubsection{Workplace trust versus Employee Monitoring}

Big Brother is becoming increasingly common. Rosengren and Ottosson (2016, p. 182-183) make the point that must be taken seriously, that while new digital technologies do open up certain kinds of monitoring and surveillance, the extent and consequences will necessarily depend on the social fabric interwoven into the organization in terms of culture and trust. We asked respondents: "Would you have more trust in your company, if monitoring software was used to track your work?" The two-point scale (yes - no) was utilized. 


\subsubsection{Productivity}

Al-Rjoub et al. (2008) emphasize that the employee will be more productive when he/she is electronically monitored. Further their results suggest that EM has been accepted by many employees as a technology tools that help in improving the employee's behaviour. The three-point scale (more productive - no effect less productive) was applied to: "How would Employee Monitoring Software affect your productivity?”

\subsubsection{Privacy versus Productivity}

The workers are using equipment supplied by their employer for both private and professional purposes. For the companies, it gives the opportunity of implementing software giving them a broader range of control and surveillance over their employees' online activities (Rosengren and Ottosson, 2016). It is increasingly common for employers to track their teams when they are on the clock. When the employees know that the Big brother is watching them, it could mean they waste less time and are more productive. But is that actually the case? The following question has been asked: "Is Employee Monitoring Software reliable?” The two-point scale was used (yes - no).

\subsubsection{Demographics}

Gender, age, marital status, and employment were used as control variables in the analyses.

\subsection{Data Analysis}

In the first stage, we used a cross-tabulation of data to examine relationships within the data. In the second stage of our analysis, we used chi-square tests statistics to find out the relationship between the pairs of questions:

- "Does your company use Employee Monitoring Software?" and "How would Employee Monitoring Software Affect your productivity?”

- "Would you have more trust in your company, if monitoring software was used to track your work?" and "Does your firm utilize Employee Monitoring Software?"

- "Would you have more trust in your company, if monitoring software was used to track your work?" and "Is Employee Monitoring Software reliable?”

- "How would Employee Monitoring Software affect your productivity?" and "Is Employee Monitoring Software reliable?”

Additionally, age group and gender has been tested of the following questions:

1. "Would you have more trust in your company if monitoring software was used to track your work?"

2. "How would Employee monitoring Software Affect your Productivity?”

3. “Is Employee Monitoring Software reliable?”

\section{Results}

\subsection{Face-to-Display workers monitoring software findings}

The oldest and most common employee monitoring technology is the clock, e.g. 8-hour day, also called the 9-to-5 workday (Duggan, 2021). Generally, it is an inaccurate method because of its focus on quantity of work instead of its quality or achievements. Monitoring of employees activities in their workplace and/or their remote place is a sensitive and often contentious issue. Rosengren and Ottosson (2016) indicate that many of the features of monitoring software are the same as those sold to parents to monitor their children's internet usage. Based on the examined data, only $1 / 5$ of respondents are aware of their organization usage of Employee Monitoring Software to track their activities (see Table 1).
Table 1: Does your company use EMS?

\begin{tabular}{|c|c|c|}
\hline Answer & Number & Ratio \\
\hline Yes & 123 & $21.0 \%$ \\
\hline No & 288 & $49.2 \%$ \\
\hline Unsure & 174 & $29.8 \%$ \\
\hline
\end{tabular}

Almost half of the e-workers surveyed think their activities are not being tracked by software. A big portion of employees is not familiar whether there is software tracking their activities (29.8 $\%)$. The proportion between Yes and No answers is 2/5. Taking this information as an input and extending it to the remaining $29.8 \%$ of the unsure ones, one gets an approximate distribution $12 / 18(2 / 3)$ of Yes/No among the rest. Based on the data and approximation, one can conclude that about $33 \%$ of employees are monitored.

Only $1 / 10$ of the face-to-display workers would trust their employer more using EMS as shown in Table 2.

Table 2: Would you have more trust in your company, if monitoring software was used to track your work?

\begin{tabular}{|c|c|c|}
\hline Answer & Number & Ratio \\
\hline Yes & 56 & $9.6 \%$ \\
\hline No & 529 & $90.4 \%$ \\
\hline
\end{tabular}

It is interesting to observe that all 56 employees responding "yes" belong to the group of 123 those familiar with their tracking in Table 2. This confirms Ball and Margulis (2011) statement that monitoring tends to focus on problems and threats, a coercive supervisory style, rather than on success and empowerment. According to Kehinde and Okafor (2019), 46.5\% of employees agree the e-monitoring facilitates an atmosphere of suspicion in the workplace. Table 3 indicates that roughly $4 / 5$ of e-workers state that EM negatively affects their productivity.

Table 3: How would EMS affect your productivity?

\begin{tabular}{|c|c|c|}
\hline Answer & Number & Ratio \\
\hline More productive & 56 & $9.6 \%$ \\
\hline No effect & 67 & $11.4 \%$ \\
\hline Less productive & 462 & $79.0 \%$ \\
\hline
\end{tabular}

Sarpong and Rees (2014) also report EM's counterproductive and negative impact on employees' productivity, commitment and attendance. They conclude that it could bring about an atmosphere of mistrust and hostility. The presented data emphasizes that the e-workers monitoring can negatively affect productivity. In the same vein, research data from Australia suggests that behaviors towards surveillance in the workplace play a crucial role in establishing whether surveillance systems and practices result in ineffective work behaviours (Martin et al., 2016). Both trust and transparency are core aspects of monitoring in the workplace (Timis and Gabelin, 2020).

Advanced technologies are allowing more diversified and prevalent monitoring and surveillance practices and are becoming more and more interlinked with data collection for the performance evaluation and management (Mateescu and Nguyen, 2019). According to Nord et al. (2006), the emonitoring reasons range from work-place harassment to a loss of productivity and even to company sabotage. A significant number of employers have been engaged in employee monitoring of various forms: from e-mail monitoring and website blocking to phone tapping and GPS tracking. The companies progressively fuse technology with policy to maintain productivity and minimize litigation, security, and other risks. To ensure conformity with rules and policies, more than $1 / 4$ of employers have dismissed workers for inappropriate use of their e-mail and nearly 1/3 have dismissed employees for incorrect use of the Internet, according to the 2007 Electronic Monitoring \& Surveillance Survey from American Management Association (AMA) and The ePolicy Institute (AMA, 2019). E-monitoring seems to be a blocking factor in e-working culture. As Table 4 indicates, the employees do not trust it. 
Table 4: Is EMS reliable?

\begin{tabular}{|c|c|c|}
\hline Answer & Number & Ratio \\
\hline Yes & 80 & $13.7 \%$ \\
\hline No & 505 & $86.3 \%$ \\
\hline
\end{tabular}

More than 4/5 of the face-to-display workers (86.3\%) believe that EM software is not reliable as shown in Table 4. This group expects the manager to define the rules and to be targetoriented. At the same time, respondents who were not used to this kind of work culture agree that EM was reliable and effective $(13.7 \%)$.

As stated by Thorstensson (2020) the productivity rises when employees have the impression that their organization has confidence in them and supports them, further supplies them with training, good project management and adequate resources to get their job done in time. In this case, the spread of Covid-19 caused many organizations problems due to a quick e-working implementation and not preparing a fair e-working culture. We agree with Kehinde and Okafor (2019) that an organization should inform employees before implementation of an EM system to produce positive reactions from employees as well as with Alder (2001) that bureaucratic cultures will answer more conducive to monitoring than supportive cultures.

\subsection{Relationships}

To learn more about the employees' attitudes, we juxtaposed their responses to the survey questions and provided their analysis.

“Does your company use Employee Monitoring Software?” and "How would Employee monitoring Software Affect your Productivity?"

Based on results of a contingency table of observed counts (see Table 5) those e-employees of companies where tracking software is used do not think that this tool reduces productivity. But all those face-to-display workers whose company does not have tracking software or are unsure about its use think that implementing of it would reduce productivity. It indicates that the companies should be open about their EMS usage and explaining its role to their employees.

Table 5: Observed Counts

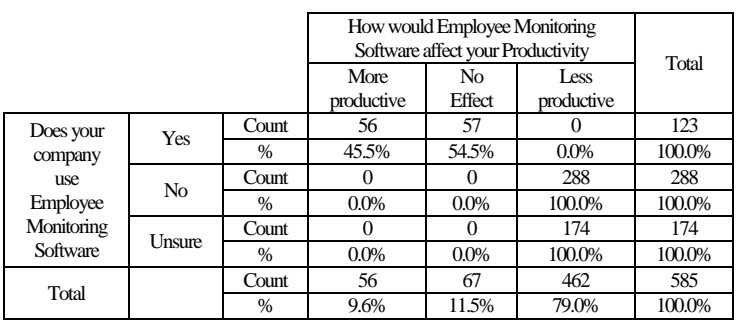

Although Table 5 of observed counts contains zero frequencies, the conditions for a good approximation for the chi-square test of independence are met. All expected counts are higher than 5 (See Table 6).

Table 6: Expected counts

\begin{tabular}{|c|c|c|c|c|c|}
\cline { 3 - 5 } \multicolumn{2}{c|}{} & \multicolumn{3}{c|}{$\begin{array}{c}\text { How would Employee monitoring } \\
\text { Software affect your Productivity }\end{array}$} & \multirow{2}{*}{ Total } \\
\cline { 3 - 5 } \multicolumn{2}{c|}{} & $\begin{array}{c}\text { More } \\
\text { productive }\end{array}$ & $\begin{array}{c}\text { No } \\
\text { Effect }\end{array}$ & $\begin{array}{c}\text { Less } \\
\text { productive }\end{array}$ & \\
\hline $\begin{array}{c}\text { Does your } \\
\text { company } \\
\text { use }\end{array}$ & Yes & 11.8 & 14.1 & 97.1 & 123.0 \\
\cline { 2 - 5 } $\begin{array}{c}\text { Employee } \\
\text { Monitoring } \\
\text { Software }\end{array}$ & No & 27.6 & 33.0 & 227.4 & 288.0 \\
\hline \multicolumn{2}{|c|}{ Total } & 16.7 & 19.9 & 137.4 & 174.0 \\
\hline \multicolumn{2}{|c|}{ Total } & 56.0 & 67.0 & 462.0 & 585.0 \\
\hline
\end{tabular}

The P-value of the test is lower than the chosen level of significance, we reject the null hypothesis of independence.
Whether a monitoring system is implemented in the company affects the subjective opinion on productivity (See Table 7).

Table 7: Chi-Square Tests

\begin{tabular}{|c|c|c|c|}
\cline { 2 - 4 } \multicolumn{1}{c|}{} & Value & df & $\begin{array}{c}\text { Asymptotic Significance (2- } \\
\text { sided) }\end{array}$ \\
\hline Pearson Chi-Square & $585.000^{\mathrm{a}}$ & 4 & 0.000 \\
\hline N of Valid Cases & 585 & & \\
\hline
\end{tabular}

a. 0 cells $(0.0 \%)$ have expected count less than 5 . The minimum expected count is 11.77 .

The final association has been measured by Cramer's V which equals to 0.707 (see Table 8) which is moderately strong and can be considered as strong relationships between variables.

Table 8: Cramer's V

\begin{tabular}{|c|c|c|c|}
\cline { 3 - 4 } \multicolumn{2}{c|}{} & Value & Approximate significance \\
\hline $\begin{array}{c}\text { Nominal by } \\
\text { Nominal }\end{array}$ & Cramer's V & 0.707 & 0.000 \\
\hline \multicolumn{2}{|l|}{ N of Valid Cases } & 585 & \\
\hline
\end{tabular}

"Would you have more trust in your company if monitoring software was used to track your work?" and "Does your firm utilize Employee Monitoring Software?”

All e-employees whose company does not have tracking software or are unsure of its utilization think that its introduction would not increase trust in the organization (see Table 9).

Table 9: Observed counts

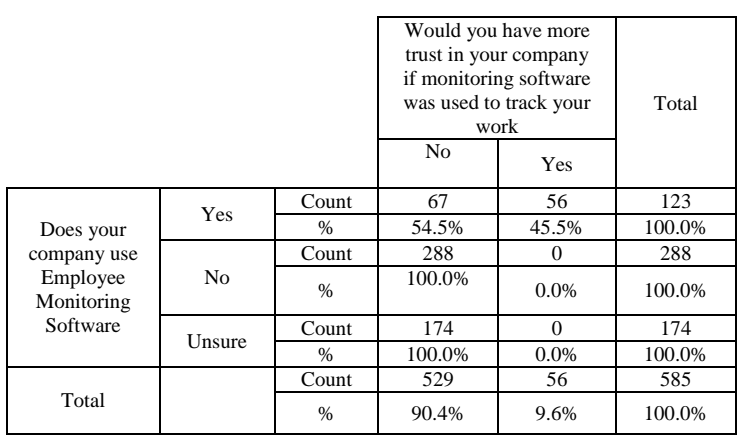

Although the table 9 of observed counts contains zero frequencies, the conditions for a good approximation for the chisquare test of independence are met.

All expected counts are higher than 5 (See Table 10).

Table 10: Expected counts

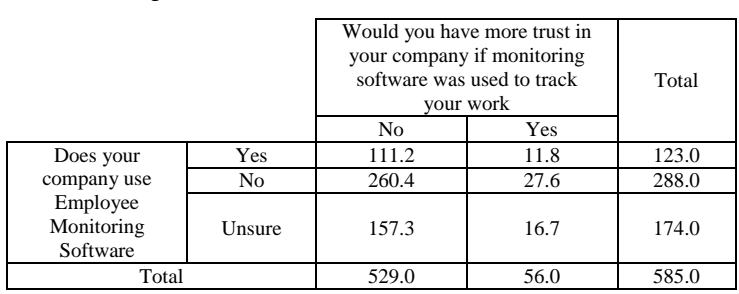

The P-value of the test is lower than the chosen level of significance, we reject the null hypothesis of independence (see Table 11). Whether the monitoring system is implemented in the company affects the subjective opinion of trust in the company.

Table 11: Chi-Square Tests

\begin{tabular}{|c|c|c|c|}
\cline { 2 - 4 } \multicolumn{1}{c|}{} & Value & df & $\begin{array}{c}\text { Asymptotic Significance (2- } \\
\text { sided) }\end{array}$ \\
\hline Pearson Chi-Square & $232.608^{\mathrm{a}}$ & 2 & 0.000 \\
\hline $\mathrm{N}$ of Valid Cases & 585 & & \\
\hline
\end{tabular}

a. 0 cells $(0.0 \%)$ have expected count less than 5 . The minimum expected count is 11.77 . 
The final association has been measured by Cramer's $\mathrm{V}$ which equals to 0.631 (see Table 12) which is moderately strong and can be considered as strong relationships between variables.

Table 12: Cramer’s V

\begin{tabular}{|c|c|c|c|}
\cline { 3 - 4 } \multicolumn{2}{c|}{} & Value & Approximate significance \\
\hline $\begin{array}{c}\text { Nominal by } \\
\text { Nominal }\end{array}$ & Cramer's V & 0.631 & 0.000 \\
\hline \multicolumn{2}{|c|}{ N of Valid Cases } & 585 & \\
\hline
\end{tabular}

"Would you have more trust in your company if monitoring software was used to track your work?" and "Is Employee Monitoring Software reliable?"

E-workers who think that monitoring software is reliable also believe in $70 \%$ that its utilization could increase confidence in the company in which they work. On the contrary, all those who doubt the reliability of monitoring software also do not believe that its implementation could increase confidence in the organization (see Table 13)

Table 13: Observed counts

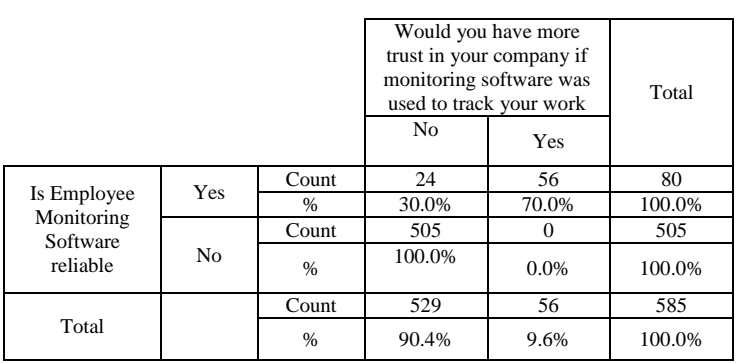

All expected counts are higher than 5 (See Table 14).

Table 14: Expected counts

\begin{tabular}{|c|c|c|c|c|}
\hline & \multicolumn{2}{|c|}{$\begin{array}{l}\text { Would you have more trust in } \\
\text { your company if monitoring } \\
\text { software was used to track your } \\
\text { work }\end{array}$} & \multirow[t]{2}{*}{ Total } \\
\hline & & No & Yes & \\
\hline \multirow{2}{*}{$\begin{array}{c}\text { Is Employee } \\
\text { Monitoring } \\
\text { Software reliable }\end{array}$} & Yes & 72.3 & $\begin{array}{l}7.7 \\
\end{array}$ & 80.0 \\
\hline & No & 456.7 & 48.3 & 505.0 \\
\hline \multicolumn{2}{|c|}{ Total } & 529.0 & 56.0 & 585.0 \\
\hline
\end{tabular}

The P-value of the test is lower than the chosen level of significance, we reject the null hypothesis of independence (see Table 15). Whether e-employees think that monitoring software is reliable affects a subjective view of trust in the company.

Table 15: Chi-Square Tests

\begin{tabular}{|c|c|c|c|}
\cline { 2 - 4 } \multicolumn{1}{c|}{} & Value & df & $\begin{array}{c}\text { Asymptotic Significance (2- } \\
\text { sided) }\end{array}$ \\
\hline Pearson Chi-Square & $390.922^{\mathrm{a}}$ & 1 & 0.000 \\
\hline N of Valid Cases & 585 & & \\
\hline
\end{tabular}

a. 0 cells $(0.0 \%)$ have expected count less than 5 . The minimum expected count is 7.66 .

The final association has been measured by Phi which equals to 0.817 (see Table 16) which is strong and can be considered as strong relationships between variables.

Table 16: Cramer’s V

\begin{tabular}{|c|c|c|c|}
\hline & & Value & Approximate significance \\
\hline Nominal by Nominal & Phi & 0.631 & 0.000 \\
\hline \multicolumn{2}{|c|}{$\mathrm{N}$ of Valid Cases } & 585 & \\
\hline
\end{tabular}

"How would Employee monitoring Software Affect your Productivity?" and "Is Employee Monitoring Software reliable?”

Most e-employees (70\%) who think that monitoring software is reliable believe that its utilization could increase work productivity. $30 \%$ of the respondents think that its utilization has no effect on labour productivity. The vast majority of e- employees (91.5\%), who do not believe in the reliability of the monitoring system, think that its introduction would reduce labor productivity (See Table 17).

Table 17: Observed Counts

\begin{tabular}{|c|c|c|c|c|c|c|}
\hline & \multicolumn{3}{|c|}{$\begin{array}{l}\text { How would Employee monitoring } \\
\text { Software affect your Productivity }\end{array}$} & \multirow[b]{2}{*}{ Total } \\
\hline & & & $\begin{array}{c}\text { More } \\
\text { productive }\end{array}$ & $\begin{array}{c}\text { No } \\
\text { Effect }\end{array}$ & $\begin{array}{c}\text { Less } \\
\text { productive }\end{array}$ & \\
\hline \multirow{4}{*}{$\begin{array}{c}\text { Is } \\
\text { Employee } \\
\text { Monitoring } \\
\text { Software } \\
\text { reliable? } \\
\end{array}$} & \multirow{2}{*}{ Yes } & Count & 56 & 24 & 0 & 80 \\
\hline & & $\%$ & $70.0 \%$ & $30.0 \%$ & $0.0 \%$ & $100.0 \%$ \\
\hline & \multirow{2}{*}{ No } & Count & 0 & 43 & 462 & 505 \\
\hline & & $\%$ & $0.0 \%$ & $8.5 \%$ & $91.5 \%$ & $100.0 \%$ \\
\hline \multirow[b]{2}{*}{ Total } & & Count & 56 & 67 & 462 & 585 \\
\hline & & $\%$ & $9.6 \%$ & $11.5 \%$ & $79.0 \%$ & $100.0 \%$ \\
\hline
\end{tabular}

Although the table 17 of observed counts contains zero frequencies, the conditions for a good approximation of the chisquare test of independence are met. All expected counts are higher than 5 (See Table 18).

Table 18: Expected counts

\begin{tabular}{|c|c|c|c|c|c|}
\cline { 3 - 5 } \multicolumn{2}{c|}{} & \multicolumn{3}{c|}{$\begin{array}{c}\text { How would Employee monitoring } \\
\text { Software affect your Productivity }\end{array}$} & \multirow{2}{*}{ Total } \\
\cline { 3 - 5 } \multicolumn{2}{c|}{} & $\begin{array}{c}\text { More } \\
\text { productive }\end{array}$ & $\begin{array}{c}\text { No } \\
\text { Effect }\end{array}$ & $\begin{array}{c}\text { Less } \\
\text { productive }\end{array}$ & \\
\hline $\begin{array}{c}\text { Is Employee } \\
\text { Monitoring } \\
\text { Software } \\
\text { reliable }\end{array}$ & Yes & 7.7 & 9.2 & 63.2 & 80.0 \\
\hline \multicolumn{2}{|c|}{ Total } & 48.3 & 57.8 & 398.8 & 505.0 \\
\hline \multicolumn{2}{|c|}{} & 56.0 & 67.0 & 462.0 & 585.0 \\
\hline
\end{tabular}

The P-value of the test is lower than the chosen level of significance, we reject the null hypothesis of independence. Whether e-employees think that a monitoring system is reliable affects a subjective view of work productivity (See Table 19).

Table 19: Chi-Square Tests

\begin{tabular}{|c|c|c|c|}
\cline { 2 - 4 } \multicolumn{1}{c|}{} & Value & df & $\begin{array}{c}\text { Asymptotic Significance (2- } \\
\text { sided) }\end{array}$ \\
\hline Pearson Chi-Square & $454.523^{\mathrm{a}}$ & 2 & 0.000 \\
\hline $\mathrm{N}$ of Valid Cases & 585 & & \\
\hline
\end{tabular}

a. 0 cells $(0.0 \%)$ have expected count less than 5 . The minimum expected count is 7.66 .

The final association has been measured by Cramer's $\mathrm{V}$ which equals to 0.881 (see Table 20) which is strong and can be considered as a strong relationship between variables.

Table 20: Cramer's V

\begin{tabular}{|l|c|c|c|}
\cline { 3 - 4 } \multicolumn{2}{c|}{} & Value & Approximate significance \\
\hline $\begin{array}{c}\text { Nominal by } \\
\text { Nominal }\end{array}$ & Cramer's V & 0.881 & 0.000 \\
\hline \multicolumn{2}{|l}{ N of Valid Cases } & 585 & \\
\hline
\end{tabular}

\subsection{Age group and gender test results}

In the next step, associations between variables (age group and gender) were tested. In the first and third questions, the effect of the answers related to age of those questions was not confirmed as $\mathrm{p}>0.05$, as shown in Table 21 and Table 22 .

Table 21: Chi-Square Tests

\begin{tabular}{|c|c|c|c|}
\cline { 2 - 4 } \multicolumn{1}{c|}{} & Value & $\mathrm{df}$ & $\begin{array}{c}\text { Asymptotic Significance (2- } \\
\text { sided) }\end{array}$ \\
\hline Pearson Chi-Square & $3.224^{\mathrm{a}}$ & 2 & 0.200 \\
\hline N of Valid Cases & 585 & & \\
\hline
\end{tabular}

a. 1 cells $(16.7 \%)$ have expected count less than 5 . The minimum expected count is 3.92 .

Table 22: Chi-Square Tests

\begin{tabular}{|c|c|c|c|}
\cline { 2 - 4 } \multicolumn{1}{c|}{} & Value & $\mathrm{df}$ & $\begin{array}{c}\text { Asymptotic Significance (2- } \\
\text { sided) }\end{array}$ \\
\hline Pearson Chi-Square & $5.403^{\mathrm{a}}$ & 2 & 0.067 \\
\hline N of Valid Cases & 585 & & \\
\hline
\end{tabular}

a. 0 cells $(0.0 \%)$ have expected count less than 5 . The minimum expected count is 5.61 . 
Related to the productivity, the effect of the answers related to age of the second question was confirmed as $\mathrm{p}<0.05$. People in age group 20-39 think less often than older generations that a monitoring system would reduce their activity (see Table 23 and 24).

Table 23: Observed Counts

\begin{tabular}{|c|c|c|c|c|c|c|}
\hline & \multicolumn{3}{|c|}{$\begin{array}{l}\text { How would Employee monitoring } \\
\text { Software affect your Productivity }\end{array}$} & \multirow[b]{2}{*}{ Total } \\
\hline & & & $\begin{array}{c}\text { More } \\
\text { productive }\end{array}$ & $\begin{array}{c}\text { No } \\
\text { Effect }\end{array}$ & $\begin{array}{c}\text { Less } \\
\text { productive }\end{array}$ & \\
\hline \multirow{6}{*}{$\begin{array}{c}\text { Age } \\
\text { group }\end{array}$} & \multirow{2}{*}{$\begin{array}{l}20- \\
39 \\
\end{array}$} & Count & 39 & 53 & 254 & 346 \\
\hline & & $\%$ & $11.3 \%$ & $15.3 \%$ & $73.4 \%$ & $100.0 \%$ \\
\hline & \multirow{2}{*}{$\begin{array}{l}40- \\
60 \\
\end{array}$} & Count & 13 & 10 & 175 & 198 \\
\hline & & $\%$ & $6.6 \%$ & $5.1 \%$ & $88.4 \%$ & $100.0 \%$ \\
\hline & \multirow{2}{*}{$60+$} & Count & 4 & 4 & 33 & 41 \\
\hline & & $\%$ & $9.8 \%$ & $9.8 \%$ & $80.5 \%$ & $100.0 \%$ \\
\hline \multirow{2}{*}{ Total } & & Count & 56 & 67 & 462 & 585 \\
\hline & & $\%$ & $9.6 \%$ & $11.5 \%$ & $79.0 \%$ & $100.0 \%$ \\
\hline
\end{tabular}

Table 24: Chi-Square Tests

\begin{tabular}{|c|c|c|c|}
\cline { 2 - 4 } \multicolumn{1}{c|}{} & Value & df & $\begin{array}{c}\text { Asymptotic Significance (2- } \\
\text { sided) }\end{array}$ \\
\hline Pearson Chi-Square & $18.206^{\mathrm{a}}$ & 4 & 0.001 \\
\hline N of Valid Cases & 585 & & \\
\hline
\end{tabular}

a. 2 cells (22.2\%) have expected count less than 5 . The minimum expected count is 3.92 .

The final association has been measured by Cramer's V which equals to 0.125 (see Table 25) which is moderate and can be considered as a moderate relationship between variables.

Table 25: Cramer's V

\begin{tabular}{|c|c|c|c|}
\cline { 3 - 4 } \multicolumn{2}{|c|}{} & Value & Approximate significance \\
\hline $\begin{array}{c}\text { Nominal by } \\
\text { Nominal }\end{array}$ & Cramer's V & 0.125 & 0.001 \\
\hline \multicolumn{2}{|c|}{ N of Valid Cases } & 585 & \\
\hline
\end{tabular}

Further investigation of gender relationships to three questions has not been confirmed. All p-values of the tests are higher than the selected significance level of 0.05 as demonstrated in Table 26, 27 and 28.

Table 26: Chi-Square Tests

\begin{tabular}{|c|c|c|c|}
\cline { 2 - 4 } \multicolumn{1}{c|}{} & Value & df & $\begin{array}{c}\text { Asymptotic Significance (2- } \\
\text { sided) }\end{array}$ \\
\hline Pearson Chi-Square & $3.506^{\mathrm{a}}$ & 1 & 0.061 \\
\hline N of Valid Cases & 585 & & \\
\hline
\end{tabular}

a. 0 cells $(0.0 \%)$ have expected count less than 5 . The minimum expected count is 25.37 .

Table 27: Chi-Square Tests

\begin{tabular}{|c|c|c|c|}
\cline { 2 - 4 } \multicolumn{1}{c|}{} & Value & df & $\begin{array}{c}\text { Asymptotic Significance (2- } \\
\text { sided) }\end{array}$ \\
\hline Pearson Chi-Square & $4.346^{\mathrm{a}}$ & 2 & 0.114 \\
\hline N of Valid Cases & 585 & & \\
\hline
\end{tabular}

a. 0 cells $(0.0 \%)$ have expected count less than 5 . The minimum expected count is 25.37 .

Table 28: Chi-Square Tests

\begin{tabular}{|c|c|c|c|}
\cline { 2 - 4 } \multicolumn{1}{c|}{} & Value & $\mathrm{df}$ & $\begin{array}{c}\text { Asymptotic Significance (2- } \\
\text { sided) }\end{array}$ \\
\hline Pearson Chi-Square & $2.671^{\mathrm{a}}$ & 1 & 0.102 \\
\hline N of Valid Cases & 585 & & \\
\hline
\end{tabular}

a. 0 cells $(0.0 \%)$ have expected count less than 5 . The minimum expected count is 36.24 .

\section{Discussion}

Based on the results of this paper, 1/5 of respondents believe that their employer use employee monitoring software to track their activities. We have shown above why $1 / 3$ is a more reasonable estimation.

To track or not track, that is a question many companies face regardless if employees are working remotely or not. Therefore, monitoring should be more closely examined to find answers for the following questions: Can we monitor everything? Should we track our talent? How to set the limits to the managers? Should the economic incentive be the main driver?

An investigation undertaken by Atlas VPN indicates that spying a single e-employee costs 7 dollars a month on average (Alex, 2020). $79 \%$ of face-to-display workers say monitoring software does affect their productivity (being less productive), comparably almost the same data as Clutch survey (Roddy, 2020). Possibly, the managers who defend EM by boosting productivity in the place of work may want to practice the following: to assuage or to eliminate bureaucracy, to revise all systems and to recognize their high quality employees, to overcome problems, to share their vision throughout the organization, to question the employees and to listen to them carefully, to be honest and to have integrity, to turn their customers into their strategic partners, and to develop effective performance-based pay plans (Moss, 2006). Skeptics also contend that there is no definitive evidence to suggest that productivity decreases because employees may be using electronic devices for non-work purposes (Riedy and Wen, 2010)

Every organization using modern technology at its workplace has got the hardware to implement monitoring. To do the electronic monitoring, any organization needs a "good" reason. The definition of "good" is, of course, unclear and depends on the environment in which it exists and the perceptions of the employees and managers (Sanders et al., 2013). Accordingly, it needs to establish (or revisit) its policies to ensure effective use depending on both sides.

The level of trust is a rule (Benetytè and Jatuliavičienè, 2013) as workplace environments rely more on trust and transparency: treated like adults, employees can do what they want, when they want, provided that the work gets done (Ressler and Thompson, 2010). This corresponds with the traditional workplace motivation theories such as Hackman and Oldham's job characteristics model that originated in 1974 and is still relevant today (Hackman and Oldham, 1974). According to Hackman and Oldham (1976) the employee's intrinsic motivation to perform effectively in their jobs is enhanced by five job characteristics: skill variety, task variety, task significance, autonomy, and feedback. The issue of employee monitoring is mainly concerning autonomy. More recent studies confirm that various forms of autonomy have positive impact on the increase in job performance caused by an increase in intrinsic motivation (Aghion et al., 2013; Beckmann et al., 2017; Bloom et al., 2011). As Deci and Ryan (2000) claim, employees who are trusted, are committed to their employers and demonstrate high intrinsic motivation in their job performance.

\section{Conclusion}

E-surveillance and e-monitoring in the workplace have developed in parallel with paradigm changes in the manufacturing industry and traditional production operations from the physical to the virtual world. Emerging technologies now enable different types of modern surveillance, often described as an oppressive Panopticon (Leth Jespersen et al., 2007) that could be used for benevolent or immoral aims. Rosengren and Ottosson (2016) say the relationship between trust and monitoring is a two-way street. It is difficult to perceive monitoring without trust as ethical or sustainable (Indiparambil, 2019). Ariss et al. (2002) advise managers to use trust rather than monitoring to increase their workers' performance. This confirms also recent studies about the e-working extension (Beno et al., 2021; Beno and Hvorecky, 2021).

The main research questions investigated in this paper are:

RQ1: Is better to leave room to e-employees instead of spying them?

Based on our results, $1 / 5$ of respondents believe that their organization uses employee monitoring software to track their 
activities. Almost half of the e-workers consider that their activities are not being tracked by software. Only nearly 1/10 of the face-to-display workers would trust their employer more using EM. Yes, out of 123 official tracked e-employees, only 56 face-to-display workers would trust their employer more using the EM and these workers state that EM does affect their productivity.

RQ2: Would e-employee monitoring software affect productivity?

Yes, roughly, 4/5 of e-workers state that EM does affect their productivity. Presented data emphasizes that companies using face-to-display workers monitoring software can negatively affect morale and productivity instead of production of good work. Moreover, Beno and Hvorecky (2021) highlight those who do not feel comfortable with e-work tend to be less productive.

RQ3: Is e-employee monitoring software reliable?

E-monitoring seems to be a blocking factor in e-working culture. Almost all e-employees (86.32\%) agree that the manager need to define the rules and be target oriented. But those respondents where the employees were not used to this kind of work culture agree that EM was reliable and effective (13.68\%).

The primary objective of this paper work was to address the issue of e-monitoring in the e-working environment. It explored the impact of monitoring on e-employees in the digital work environment whether tracking the employees' activities in eworkplace represents an optimal factor in e-working culture. EM started in the past as tracking web browsing, online shopping, checking social media or looking at sports scores. A study by Greenfield and Davis (2002) highlight that the respondents spent an average of 3.24 hours per week on personal Internet usage while at work. Additionally, around $14 \%$ of the UK workforce spends almost half of their time on the Internet for personal use (Newcombe, 2013). Modern technology, diversity in technological capabilities and not necessarily ethical outlook (Pitesa, 2012) and e-working enables tracking of employees activities. A recent study highlights the rise of surveillance software (51\%) since the start of pandemic (Migliano, 2020). But e-monitoring seems to be a blocking factor in e-working culture. EM can create a lack of trust (Mujtaba, 2003). The Deloitte Global Millennial survey of 2019 found that 55\% of millennials plan to leave employers that prioritize profits over people (Deloitte, 2019).

Topics revealed in this paper have implications for future research in the area of monitoring the e-workers. Future researchers must begin by exploring these issues directly with those who face them (a qualitative approach). Important seems to be the post-Covid-19 time of the workplace environment in trying to establish some form of balance or harmony between all parties in the e-working, hybrid and cubicle workplace environment. The authors leave all these questions for future research: Are there individual pros of e-monitoring compared to alternatives?, Will employees agree with the willingly selfmonitoring? and can accepted and transparent e-monitoring still be immoral?

This paper has some limitations. Firstly, data gathering occurred by means of e-mail questionnaires because of distance, economic aspects and pandemic. There is no guarantee that the researchers drew all possible information from the participants that could be used in the analysis of the data and results. However, the quality of the data depends upon the quality of the questions asked (Beno and Hvorecky, 2021). Secondly, the sample does not reflect the population by sectoral structure. Thirdly, because of time lack the questionnaire were not translated into mother languages of respondents. Lastly, the researchers have no way of ascertaining whether the respondents replied honestly or not. It should be stated that results from this study do not necessarily reflect how workers used to work (in-house, hybrid or remote) will evolve in the post-pandemic period.

\section{Literature:}

1. Aghion, P., Bloom, N., \& Van Reenen, J.: Incomplete contracts and the internal organization of the firm. The Journal of Law, Economics, \& Organization, vol. 30, no. 1/2013, pp. i37-i63. https://doi.org/10.1093/jleo/ewt003

2. Ajunwa, I., Crawford, K., \& Schultz, J.: Limitless Worker Surveillance, 2017. 105 California Law Review, 735/2017 Available at: https://ssrn.com/abstract $=2746211$

3. Alder, G. S.: Employee reactions to electronic performance monitoring: A consequence of organizational culture. The Journal of High Technology Management Research, vol. 12, no. 2/2001, pp. 323-342. https://doi.org/10.1016/S1047-8310(0 1)00042-6

4. Alex, T.: It Costs \$7 For Your Boss to Monitor You Working Remotely, 2020. Available at: https://atlasvpn.com/blog/it-costs7-for-your-boss-to-monitor-you-working-remotely 5. Al-Rjoub, H., Zabian, A., \& Qawasmeh, S.: Electronic monitoring: The Employees Point of view. Journal of Social Sciences, vol. 4, no. 3/2008, pp. 189-195. https://doi.org/10.3844 /jssp.2008.189.195

6. Allen, T. D., Golden, T. D., \& Shockley, K. M.: How effective is telecommuting? Assessing the status of our scientific findings. Psychological Science in the Public Interest, vol. 16, no. 2/2015, pp. 40-68. https://doi.org/10.1177/15291006155 93273

7. AMA: The Latest on Workplace Monitoring and Surveillance, 2019. Available at: https://www.amanet.org/articles/the-lateston-workplace-monitoring-and-surveillance/

8. Amabile, T. M., Conti, R., Coon, H., Lazenby, J., \& Herron, M.: Assessing the work environment for creativity. Academy of Management Journal, vol. 39, no. 5/1996, pp. 1154-1184. https://doi.org/10.5465/256995

9. Ariss, S. S.: Computer monitoring: benefits and pitfalls facing management. Information \& Management, vol. 39, no. 7/2002, pp. 553-558. https://doi.org/10.1016/S0378-7206(01)00121-5

10. Ball, K.: Workplace surveillance: an overview. Labour History, vol. 51, no. 1/2010, pp. 87-106. https://doi.org/10.1080/ 00236561003654776

11. Ball, K. S., \& Margulis, S. T.: Electronic monitoring and surveillance in call centres: a framework for investigation. New Technology, Work and Employment, vol. 26, no. 2/2011, pp. 113-126. https://doi.org/10.1111/j.1468-005X.2011.00263.x

12. Baruch, Y., \& Nicholson, N.: Home, Sweet Work: Requirements for Effective Home Working. Journal of General Management, vol. 23, no. 2/1997, pp. 15-30. https://doi.org/10.1 177/030630709702300202

13. Beckmann, M., Cornelissen, T., \& Kräkel, M.: Self-managed working time and employee effort: Theory and evidence. Journal of Economic Behavior \& Organization, vol. 133, 2017, pp. 285-302. https://doi.org/10.1016/j.jebo.2016.11.013

14. Benetytè, D., \& Jatuliavičiené, G.: Building and sustaining trust in virtual teams within organizational context. Regional Formation and Development Studies, vol. 10, no. 2/2013, pp. 1830. http://dx.doi.org/10.15181/rfds.v10i2.138

15. Beno, M.: Transformation of Human Labour from Stone Age to Information Age. In Younas M., Awan I., Ghinea G., Catalan Cid M. (eds), Mobile Web and Intelligent Information Systems. MobiWIS 2018. Lecture Notes in Computer Science, vol. 10995, 2018, pp. 205-216. https://doi.org/10.1007/978-3-319-971636_17

16. Beno, M.: Four Factors that will shape the Future of Work. Journal on Advances in Theoretical and Applied Informatics, vol. 5, no. 1/2019, pp. 1-7. https://doi.org/10.26729/jadi.v5i1.3 114

17. Beňo, M.: The Advantages and Disadvantages of E-working: An Examination using an ALDINE Analysis. Emerging Science Journal, vol. 5, 2021, pp. 11-20. Doi: 10.28991/esj-2021-SPER-02

18. Beno, M., \& Hvorecky, J.: Data on an Austrian Company's Productivity in the Pre-Covid-19 Era, During the Lockdown and After Its Easing: To Work Remotely or Not? Frontiers Communication, vol. 6, no. 641199/2021, pp. 1-10. https://doi.o $\mathrm{rg} / 10.3389 /$ fcomm.2021.641199

19. Beno, M., Hvorecky, J., \& Caganova, D.: An Optimal eworking Environment: Online Survey Results. International 
Journal of Business and Applied Social Science, vol. 7, no. 2/2021, pp. 1-10. DOI: 10.33642/ijbass.v7n2p1

20. Bernstrøm, V. H., \& Svare, H.: Significance of Monitoring and Control for Employees' Felt Trust, Motivation, and Mastery. Nordic Journal of Working Life Studies, vol. 7, no. 4/2017, pp. 29-49. https://doi.org/10.18291/njwls.v7i4.102356

21. Bhave, D. P.: The Invisible Eye? Electronic Performance Monitoring and Employee Job Performance. Personnel Psychology, vol. 67, no. 3/2014, pp. 605-635. https://doi.org/1 0.1111 peps.12046

22. Bloom, N., \& Van Reenen, J. M.: Human resource Management and Productivity. Handbook of Labor Economics, vol. 4b, 2011, pp. 1697-1767.

23. Burawoy, M.: Manufacturing Consent: Changes in the Labour Process Under Monopoly Capitalism. USA: University of Chicago Press, 1982. $286 \mathrm{p}$.

24. Ciocchetti, C. A.: The Eavesdropping Employer: A Twenty-first Century Framework for Employee Monitoring. American Business Law Journal, vol. 48, no. 2/2011, pp. 285369. https://doi.org/10.1111/j.1744-1714.2011.01116.x

25. Deci, E. L., \& Ryan, M. R.: The "What" and "Why" of Goal Pursuits: Human Needs and the Self-Determination of Behavior. Psychological Inquiry, vol. 11, no. 4/2000, pp. 227268. https://doi.org/10.1207/S15327965PLI1104 01

26. Deloitte: The Deloitte Global Millennial Survey 2019, 2019. Available at: https://www2.deloitte.com/content/dam/Deloitte/g lobal/Documents/About-Deloitte/deloitte-2019-millennial-surv ey.pdf

27. Duggan, Ch.: Employee monitoring: to track or not to track?, 2021. Available at: https://resources.workable.com/stories-andinsights/employee-monitoring

28. Eurofound: Living, working and COVID-19, COVID-19 series. Luxemburg: Publications Office of the European Union, 2020.

29. Foucault, M.: Discipline and punish: the birth of the prison. New York: Vintage Books, 1979. 333 p.

30. Fracaro, K. E.: The Consequences of Micromanaging. Contract management, vol. 47, no. 7/2007, pp. 4-8.

31. Gajendran, S. R., \& Harrison, A. D.: The good, the bad, and the unknown about telecommuting: Meta-analysis of psychological mediators and individual consequences. Journal of Applied Psychology, vol. 92, no. 6/2007, pp. 1524-1541. https://doi.org/10.1037/0021-9010.92.6.1524

32. Greenfield, D. N., \& and Davis, R. A.: Lost in cyberspace: The web @ work. Cyber-Psychology and Behavior, vol. 5, no. 4/2002, pp. 347-353. https://doi.org/10.1089/109493102760275590

33. Hackman, J. R. \& Oldham, G. R.: The job diagnostic survey: An instrument for the diagnosis of jobs and the evaluation of job redesign projects. Department of Administrative Sciences: Yale University, 1974

34. Hackman, J. R., \& Oldham, G. R.: Motivation through the design of work: Test of a theory. Organizational Behavior and Human Performance, vol. 16, no. 2/1976, pp. 250-279. https://doi.org/10.1016/0030-5073(76)90016-7

35. Harrison, D. A., Johns, G., \& Martocchio, J. J.: Changes in Technology, teamwork, and diversity: New directions for a new century of absenteeism research. Research in Personnel and Human Resources Management, 18(1)/2000, pp. 43-92.

36. Hunton, J. E., \& Norman, C. S.: The Impact of Alternative Telework Arrangements on Organizational Commitment: Insights from a Longitudinal Field Experiment. Journal of Information Systems, vol. 24, no. 1/2010, pp. 67-90. https://doi.org/10.2308/jis.2010.24.1.67

37. Indiparambil, J. J.: Privacy and beyond: socio-ethical concerns of 'on-the-job' surveillance. Asian Journal of Business Ethics, vol. 8, 2019, pp. 73-105. https://doi.org/10.1007/s13520019-00089-0

38. Kehinde, O. J., \& Okafor, E. E.: The use of electronic monitoring and work performance of employees in the banking industry in Ibadan, Southwest Nigeria. African Journal of Business Management, vol. 13, no. 10/2019, pp. 327-342. https://doi.org/10.5897/AJBM2019.8764

39. Kirsten, M., \& Freeman, R. E.: Some Problems with Employee Monitoring. Journal of Business Ethics, vol. 43, no. 4/2003, pp. 353-361. https://doi.org/10.1023/A:1023014112461
40. Kiziloglu, M.: A research on the relationship between workplace monitoring and jobs stress. Journal of Organizational Behavior Research, vol. 3, no. 2/2018, pp. 1-12.

41. Kropp, B.: The Future of Employee Monitoring, 2019. Available at: https://ink.library.smu.edu.sg/lkcsb_research/5031 42. Kurland, B. N., \& Bailey, E. D.: Telework: The advantages and challenges of working here, there, anywhere, and anytime. Organizational Dynamics, vol. 28, no. 2/1999, pp. 53-68. https://doi.org/10.1016/S0090-2616(00)80016-9

43. Laudon, K. C., \& Laudon, J. P.: Management Information Systems. Essex: Pearson Education Limited, 2018. 639 p.

44. Leth Jespersen J., Albrechtslund A., Øhrstrøm P., Hasle P., \& Albretsen J.: Surveillance, Persuasion, and Panopticon. In: de Kort Y., IJsselsteijn W., Midden C., Eggen B., Fogg B.J. (eds) Persuasive Technology. PERSUASIVE 2007. Lecture Notes in Computer Science, 4744. Springer, Berlin, Heidelberg, 2007, pp. 109-120. https://doi.org/10.1007/978-3-540-77006-0_15 45. Lim, V. K. G.: The IT way of loafing on the job: Cyberloafing, neutralizing and organizational justice. Journal of Organizational Behaviour, vol. 23, no. 5/2002, pp. 675-694. https://doi.org/10.1002/job.161

46. Liu, Y.: Employee Monitoring: Workplace as a Panopticon?, 2017. Available at: https://thesiscommons.org/y7m6c/

47. Martin, K., \& and Freeman, R. E.: Some problems with employee monitoring. Journal of Business Ethics, 43(4)/2003, pp. 353-361. https://doi.org/10.1023/A:1023014112461

48. Martin, A. J., Wellen, J. M., \& Grimmer, M. R.: An eye on your work: How empowerment affects the relationship between electronic surveillance and counterproductive work behaviours. The International Journal of Human Resource Management, vol. 27, no. 21/2016, pp. 2635-2651. https://doi.org/10.1080/0958 5192.2016.1225313

49. Mateescu, A., \& Nguyen, A.: Workplace Monitoring \& Surveillance, 2019. Available at: https://datasociety.net/wpcontent/uploads/2019/02/DS_Workplace_Monitoring_Surveillan ce_Explainer.pdf

50. Migliano, S.: Employee Surveillance Software Demand up 51\% Since Start of Pandemic, 2020. Available at: https://www.top10vpn.com/research/investigations/covid-emp loyee-surveillance/

56. Moss, G.: Business secrets: Guidelines for New LeadersManagers. USA: Cengage Learning, 2006. 300 p.

57. Moussa, M.: Monitoring Employee Behavior Through the Use of Technology and Issues of Employee Privacy in America. Sage Open, vol. 5, no. 2/2015, pp. 1-13. https://doi.org/10.1177/2158244015580168

58. Mujtaba, B.: (2003). Ethical implications of employee monitoring: What leaders should consider. Journal of Applied Management and Entrepreneurship, vol. 8, no. 3/2003, pp. 22-47.

59. Newcombe, T.: Employees spend up to half the working day surfing the internet for personal use, says K3 Managed Services, 2013. Available at: https://www.hrmagazine.co.uk/articledetails/employees-spend-up-to-half-the-working-day-surfingthe-internet-for-personal-use-says-k3-managed-services 60. Nicklin, J. M., Cerasoli, Ch. P., \& Dydyn, K. L.: Telecommuting: What? Why? When? and How? In Jungwoo Lee (eds), The impact of ICT on work. Singapore: Springer, 2016, pp. 41-70. https://doi.org/10.1007/978-981-287-612-6_3 61. Nilles, M. J., Gray, P., Carlson, F. R., \& Hanneman, J. G. Telecommunications-Transportation Tradeoff. National Science Foundation, 1974

62. Nilles, J. M.: Telework: Enabling Distributed Organizations. Information Systems Management, vol. 14, no. 4/1997, pp. 7-14. https://doi.org/10.1080/10580539708907069

63. Nilles, J. M.: Making Telecommuting Happen: A Guide for Telemanagers and Telecommuters. New York: John Wiley \& Sons, 1994.

64. Nilles, J. M.: Managing Telework: Strategies for Managing the Virtual Workforce. New York: John Wiley \& Sons, 1998. 65. Nord, G. D., McCubbins, T. F., \& Horn Nord, J.: Emonitoring in the workplace: privacy, legislation, and surveillance software. Communications of the ACM, vol. 49, no. 8/2006, pp. 72-77. https://doi.org/10.1145/1145287.1145290 66. Pitesa, M.: Employee surveillance and the modern workplace. Business Ethics: A critical approach: Integrating 
ethics across the business world, 2012, pp. 206-219. Available at: https://ink.library.smu.edu.sg/lkcsb_research/5031

67. Porterfield, R. L.: The perils of micromanagement. Contract Management, vol. 43, no. 2/2003, pp. 20-23.

68. Princi, E., \& Krämer, N. C.: Acceptance of Smart Electronic Monitoring at Work as a Result of a Privacy Calculus Decision. Informatics, vol. 6, no. 3/2019, pp. 19. https://doi.org/10.33 90/informatics6030040

69. Ressler, C., \& Thompson, J.: Why work sucks and how to fix it. New York: Portfolio, 2010. 256 p.

70. Riedy, M., \& Wen, J.: Electronic surveillance of internet access in the American workplace. Information and Communication Technology Law, vol. 19, no. 1/2010, pp. 87-99. https://doi.org/10.1080/13600831003726374

71. Roddy, S.: Pros and Cons of Employee Monitoring, 2020. Available at: https://clutch.co/hr/resources/pros-cons-employeemonitoring\#: :text=Only\%2010\%25\%20of\%20employees\%20s ay\%20that\%20they\%20would\%20have\%20more,used\%20to\%2 0track\%20their\%20work

72. Rosengren, C., \& Ottosson, M.: Employee monitoring in a digital context. In J. Daniels, K. Gregory, \& T. McMillan Cottom (Eds.), Digital sociologies. Policy Press, 2016, pp. 181-194.

73. Sanders, D., Ross, J., \& Pattison, P.: Electronic snoops, spies, and supervisory surveillance in the workplace. Southern Law Journal, vol. 23, 2013, pp. 1-27.

74. Sarpong, S, \& Rees, D.: Assessing the effects of 'big brother' in a workplace: The case of WAST. European Management Journal, vol. 32, no. 2/2014, pp. 216-222. https://doi.org/10.1016/j.emj.2013.06.008

75. Schiff, F.: Working at Home Can Save Gasoline, 1979. Available at: https://www.washingtonpost.com/archive/opinio ns/1979/09/02/working-at-home-can-save-gasoline/ffa475c7d1a8-476e-8411-8cb53f1f3470/

76. Schumacher, S.: What Employees Should Know About Electronic Performance Monitoring. ESSAI, vol. 8, no. 38/2011, pp. 138-144.

77. Shin, S. J., \& Zhou, J.: Transformational Leadership, Conservation, and Creativity: Evidence from Korea. Academy Management Journal, vol. 46, no. 6/2017, pp. 703-714. https://doi.org/10.5465/30040662

78. Solon, O.: Big Brother isn't just watching: workplace surveillance can track your every move, 2017. Available at: https://www.theguardian.com/world/2017/nov/06/workplacesurveillance-big-brother-technology

79. TechRepublic: Issues to consider when implementing an employee monitoring program, 2005. Available at: https://www.techrepublic.com/article/issues-to-consider-whenimplementing-an-employee-monitoring-program/

80. Thorstensson, E.: The influence of Working from Home on Employees' productivity, 2020. Available at: https:/www.divaportal.org/smash/get/diva2:1446903/FULLTEXT01.pdf

81. Timis, D., \& Gabelin, O.: The Rise of Employee Monitoring in the Workplace, 2020. Available at: https://www.globalsolutions-initiative.org/young-global-changers-blog/employeemonitoring-in-the-workplace/

82. Virgona, C., Waterhouse, P., Sefton, R., \& Sanguinetti, J.: Making experience work: Generic skills through the eyes of displaced workers, 2003. Available at: https://www.ncver.ed u.au/_data/assets/file/0019/6409/nr1007vol1.pdf

83. Workflexibility: Remote Work or Telecommute: What's the Difference, 2018. Available at: https://www.workflexibilit y.org/remote-work-vs-telecommute-whats-the-difference/

\section{Primary Paper Section: A}

Secondary Paper Section: AE, AH, AP 